\title{
CUTTING TYPES COLLECTED AT DIFFERENT SEASONS ON BLACKBERRY MULTIPLICATION ${ }^{1}$
}

\author{
IBRAR HUSSAIN², SERGIO RUFFO ROBERTO ${ }^{3}$, RONAN CARLOS COLOMBO $^{4}$, \\ ADRIANE MARINHO DE ASSIS ${ }^{5}$, RENATA KOYAMA 6
}

\begin{abstract}
Blackberry is a shrubby perennial tree with high economic importance among horticultural crops in several countries. The fruit has a good market value, both at national and international level. The objective of this work was to evaluate the multiplication of blackberry cv. Xavante cuttings under different seasons over the year, aiming to improve the production of nursery plants. The experiment was carried out from April 2012 to March 2013 and it was laid out in randomized complete block design with different types of cutting: tip, softwood, semihardwood and root, examined in different seasons: autumn, spring and summer, with 5 replications and 10 cuttings per plot. The variables studied were: cutting rooting, cutting survival, number of roots, length of major roots and roots dry weight. Cuttings of blackberry had a significant temporal variation in the percentage of successful rooting and survival of cuttings. It was verified that softwood and semihardwood cuttings collected in summer are the best option for blackberry cv. Xavante multiplication for commercial production of nursery plants.
\end{abstract}

Index terms: Rubus spp., vegetative propagation, 'Xavante' blackberry.

\section{TIPOS DE ESTACAS E ESTAÇÃO DO ANO NA MULTIPLICAÇÃO DA AMOREIRA-PRETA}

RESUMO-A amoreira-preta é uma planta arbustiva e perene de relevante importância econômica entre as culturas frutíferas cultivadas no mundo e apresenta frutos de bom valor de mercado, seja nacional seja internacional. O objetivo do trabalho foi avaliar o enraizamento de diferentes tipos de estacas de amoreira-preta cv. Xavante em três estações do ano. O ensaio foi conduzido entre abril de 2012 e março de 2013, no outono, primavera e verão, utilizando estacas de ponteiro, herbácea, semilenhosa e raiz. O delineamento experimental foi o em blocos casualizados, com cinco repetições e 10 estacas por parcela. As variáveis estudadas foram: porcentagem de sobrevivência e enraizamento, número de raízes por estaca, comprimento e massa seca das raízes. As estacas de amoreira-preta apresentaram significativo impacto temporal na porcentagem de enraizamento e sobrevivência. Estacas herbáceas e semilenhosas, coletadas durante o verão, são as melhores opções para a multiplicação comercial de mudas da amoreira-preta cv. Xavante.

Termos para indexação: Rubus spp., propagação vegetativa, amora-preta 'Xavante'.

\footnotetext{
${ }^{1}$ (Paper 007-16). Received January 12, 2016. Accepted October 04, 2016.

${ }^{2}$ Agronomist, Ph.D, Centro de Ciências Agrárias, Universidade Estadual de Londrina, P.O. Box 10.011, ZIP 86.057-970, LondrinaPR, Brazil. E-mail: ibrar_horti@yahoo.com.

${ }^{3}$ Agronomist, Ph.D, Centro de Ciências Agrárias, Universidade Estadual de Londrina, P.O. Box 10.011, ZIP 86.057-970, Londrina-PR, Brazil. E-mail: sroberto@uel.br (Corresponding author)

${ }^{4}$ Agronomist, Ph.D, Centro de Ciências Agrárias, Universidade Estadual de Londrina, P.O. Box 10.011, ZIP 86.057-970, LondrinaPR, Brazil. E-mail: ronancolombo@yahoo.com.br.

${ }^{5}$ Agronomist, Ph.D, Departamento de Produção Vegetal, Universidade Federal de Pelotas, ZIP 96.160-000, Pelotas, RS, Brazil. E-mail: agroadri@ig.com.br.

${ }^{6}$ Agronomist, Ph.D, Centro de Ciências Agrárias, Universidade Estadual de Londrina, P.O. Box 10.011, ZIP 86.057-970, Londrina-PR, Brazil. E-mail: emykoyama@hotmail.com.
} 


\section{INTRODUCTION}

The blackberry (Rubus spp.) is a perennial fruit tree which belongs to Rosaceae family, presenting shrubby structure. There are over 740 species around the world with five found in Brazil, which provides fruits of different colors, such as white, red and black (HARBORNE; WILLIAMS, 2000; CLARK; FINN, 2014).

Blackberries have become a common fruit in North America and European Union, worldwide cultivated on almost 25,000 ha (CLARK; FINN, 2014). In Brazil, the main producing area is Rio Grande do Sul (RS), but other regions with favorable microclimate, such as Minas Gerais, São Paulo, Santa Catarina and Parana have high potential for growing this fruit tree (VILLA et al., 2003).

The use of high quality nursery plants is one of the keys to obtain success in blackberry cultivation. Traditionally, this species has been propagated using vegetative methods, including tip layering, cane cuttings (soft and hard), root cuttings, and tissue culture (CALDWELL, 1984), which enables the achievement of large quantity of nursery plants in a short time (ANTUNES; RASEIRA, 2004; MAIA; BOTELHO, 2008; YAMAMOTO et al., 2013). Depending on the type or variety of blackberry, nursery plants can be produced by layering, stem and root cuttings (CLARK; FINN, 2014). However, stem cutting is considered the simplest and most economical method of vegetative propagation practiced in horticultural industry for mass production within a short time (YOO; KIM, 1996). In general, softwood cuttings can root more easily and more quickly than hardwood cuttings (KASIM et al., 2009).

The success of vegetative propagation through cuttings depends on several factors, such as the genetic potential of rooting, physiological conditions of the mother plant, season of year, hormonal balance, temperature, light and humidity (SOUNDY et al., 2008). Total carbohydrate and total nitrogen levels, and $\mathrm{C} / \mathrm{N}$ ratio have been reported to influence the adventitious rooting of some species (RAPAKA et al., 2005). These substances are source of carbon and energy for biosynthesis of nucleic acids and proteins, in addition to the synthesis of other essential substances to root formation. Cuttings with high levels of carbohydrates generally have better rooting percentage (HARTMANN et al., 2002; FACHINELLO et al., 2005), but these levels can change substantially depending of the season of the year. Seasonal variation in rooting efficiency is very common in woody plants, and the optimal season for rooting must be established individually for each species (HUSSAIN et al., 2012, 2014; YAMAMOTO et al., 2013).

For commercial nursery plant production, the season of the year can be a limiting factor due the availability of propagation material, and in some cases, it only occurs during pruning occasion, when a considerable amount of branches is removed (PAULA et al., 2009). The propagation season can be also evaluated and adjusted to the pruning occasion of some species, what usually occurs at late winter in subtropical regions. Thus, the propagation material is often used since the cuttings are discharged after this operation. To avoid it, stock plants can be kept in greenhouses in order blackberry cuttings can be used for nursery production all year round, and not only after winter pruning, improving the nursery production system. However, there is a lack of information regarding the blackberry cutting rooting performance throughout the main seasons of the year, especially in subtropical conditions.

Considering the aspects above, the objective of the study was to evaluate the effect of cutting types collected in different seasons of the year for large-scale multiplication of blackberry cv. Xavante.

\section{MATERIAL AND METHODS}

The trial was carried out from April 2012 to March 2013 at Universidade Estadual de Londrina, PR, Brazil (latitude $23^{\circ} 23 \mathrm{~S}$, longitude $51^{\circ} 11 \mathrm{~W}$ and elevation of $566 \mathrm{~m}$ ). According to Köppen, the local climate is $\mathrm{Cfa}$ (subtropical humid). The genetic material of blackberry cv. Xavante was obtained from stock plants of EMBRAPA, Pelotas, RS in 2011.

The experiment was laid out in randomized complete block design with 5 replications and 10 cuttings per plot. The treatment consisted of different cutting types: tip, softwood, semihardwood and roots cutting, collected in different seasons: autumn (mid April, 2012), spring (early September, 2012) and summer (mid December, 2012).

The cuttings were collected from well established trees from different portion of each branch. The cuttings were trimmed to $10-12 \mathrm{~cm}$ just below the node, and the leaves near to the basal portion were removed, leaving a pair of leaves at the top. The root cuttings were collected from uprooted pot plants, and the soil was removed and roots were washed with water. The cuttings were taken from the roots and placed in a plastic basin with water to avoid dehydration. All cutting types were planted in perforate plastic trays $(44 \times 30 \times 7 \mathrm{~cm})$ containing carbonized rice husk coal as rooting substrate. 
Each plastic tray containing the well-spaced and distributed cuttings $(n=10)$ consisted of a plot.

The trays were placed in a mist chamber inside a greenhouse covered with transparent polyethylene film and $30 \%$ shading. The relative humidity was controlled by an intermittent timer and a solenoid valve programmed to mist during 10 seconds every three minutes. The nozzle nebulizer employed (Model DanSprinklers Mist, Israel) presents flow of $35 \mathrm{~L} \cdot \mathrm{hr}^{-1}$. The daily mean average of temperature $\left({ }^{\circ} \mathrm{C}\right)$ and average relative humidity $(\%)$ recorded during the trials are presented in Figure 1.

After 90 days, the following variables were evaluated: cutting rooting ( $\%$ of cuttings which issued at least one major root), cutting survival (\% of alive cuttings); number of roots per cutting, length of major roots per cutting $(\mathrm{cm})$ and dry weight of roots per cutting (g). The root dry mass was obtained by drying it in an oven with forced air at $78^{\circ} \mathrm{C}$ for $48 \mathrm{~h}$.

The data were submitted to analysis of conjoint variance of experiments in different seasons and means were compared by Tukey's test at $5 \%$ probability.

\section{RESULTS AND DISCUSSION}

All cutting types showed means of rooting percentage higher than $62 \%$ when propagated in summer and spring, except tip cuttings, which had higher rooting $(88 \%)$ when propagated in autumn (Table 1). Softwood cuttings presented percentage of rooting higher than $64 \%$, independent of the season. On the other hand, semihardwood cuttings presented high percentage of rooting in spring and summer ( $88 \%$ and $94 \%$, respectively), while tip cuttings presented means less than $50 \%$, as there are more sensitive to the higher temperatures verified in spring and summer (Figure 1).

The results of cutting survival percentage followed the same trend observed for those of cutting rooting, showing means once in a while slightly higher (Table 2). It occurs because sometimes the callus on the base of the cutting if formed, but with no roots formation (PICOLOTTO et al., 2015). Tip cuttings had lower survival when collected in spring and summer, and higher in autumn. As previously commented for rooting cutting, it may have occurred because during spring and summer, the air temperature is higher than autumn, and tip cuttings are very sensitive to drought. Root cutting varied significantly when multiplied under timing, with 98 and 96\% survival in autumn and spring, respectively, and $68 \%$ in summer season.
Besides the mother plant conditions, it is known that the high efficiency of adventitious root in blackberry stem cuttings depends of other factors (SOUNDY et al., 2008), and for this reason, the results observed for other authors not always are alike, even though when the same aim is pursued. When semihardwood and softwood cuttings of 'Xavante' blackberry were collected in summer, it was obtained $85 \%$ of rooting (YAMAMOTO et al., 2013). It has been observed the high rooting potential of blackberry softwood cuttings collected during the growing season, especially in spring and summer, with means ranging from $80 \%$ to $100 \%$ (ANDRADE et al., 2007; DIAS et al., 2011). On the other hand, when blackberry woody cuttings are collected in winter and spring, the percentage of rooting is significantly reduced (MOREIRA et al., 2012; VILLA et al., 2003), or simply, it does not occur (MAIA; BOTELHO, 2008).

In some cases, the use of root cuttings to multiply 'Tupy' blackberry is preferred due its higher rate of rooting when collected in the beginning of spring (CAMPAGNOLO; PIO, 2012). It was observed that there is a complex relationship between the cutting type and the season of the year. The environmental conditions alter, with no doubt, the chemical composition of cuttings and it can influence the rooting. As in summer season the quantity of sunlight hours is higher in subtropical areas, herbaceous cuttings under these conditions are favored by higher production of photosynthesized compounds (PAULA et al., 2009). The season of the year may also influence the rooting, and in the case of herbaceous cuttings, the better results are obtained throughout the growing season, i.e., in spring-summer (HARTMANN et al., 2002). The influence of the season of the year on root induction also can be caused due the reserve of nutrients in the cambial tissues and the cambial activity, as well due the endogenous auxins present in the cuttings or cuttings stage of development (LEITE; MARTINS, 2007; OHLAND et al., 2009).

Thus, superior rooting of cuttings occurred in spring and mid of summer may be due to the cause and/or effect of growth and mobilization of metabolites, since the both seasons of collecting and age of cuttings are correlated which directly influence success of cutting (SWAMY et al., 2002).

The lower performance of rooting when softwood and hardwood cuttings were collected in autumn in comparison to tip cuttings may be explained by several factors, such as air temperature, stock plant conditions, cuttings photosynthetic and transpiration rates and carbohydrate production 
(YOO; KIM, 1996). The air temperature can be related with metabolic activities in cuttings tissues, water relations as well the rooting medium temperature. High temperatures can cause the enzymes denaturation or reducing enzymatic activity (SALMI; HESAMI, 2016). In subtropical conditions, the berries production and harvest of blackberry 'Xavante' occurs in spring and summer (HUSSAIN et al., 2016; 2017). So, it is possible that plants in autumn presents lower carbohydrate reserves due the berries production, which can affect the cuttings quality ant rooting.

The different fruit plant species respond to this situation also in different ways. Rahman et al. (1991) reported that the number of roots of semihardwood cuttings of guava (Psidium guajava) is higher in summer due the higher metabolic activities in the plants which helps the cuttings to have optimum development. On the other hand, Silva et al. (2012) reported that the cutting type affects the number of roots in black raspberry (Rubus niveus), where the basal stem cutting presents better results in comparison to root cuttings in summer. For pomegranate (Punica granatum), the basal cutting collected in summer is also a good option for propagation due its higher amount of carbohydrates (HUSSAIN et al., 2012). Thus, for 'Xavante' blackberry multiplication, it was possible to verify that is preferred to use softwood and hardwood cutting collected in spring and summer seasons when the plant metabolism is high, instead of those collected in autumn, where the plant presents low activity.

Regarding the number of roots per cutting, there was no significant difference in spring and summer among cuttings types (Table 3 ), except for tip cuttings in autumn, which presented the highest mean when propagated in this season. Root length was significantly affected by different seasons of propagation, but no interaction between factors has been observed (Table 4). Maximum root length was recorded in summer followed by spring and minimum in autumn. The higher root length in summer may be attributed to the favorable temperature, optimum humidity and longer day length. Similar values to root length of major root $(31.5 \mathrm{~cm})$ in blackberry (Rubus spp.) propagated in spring in rice husk as substrate was also observed (DIAS et al., 2011).
Higher temperatures and water availability can promote high root grow rates (CONTADOR et al., 2015), and it explains the results found in summer and spring in this work.

Roots dry weight was significantly affected by different types of cuttings and seasons, and also the interaction varied significantly (Table 5). Among types of cuttings, the highest root dry weight mean was recorded in tip cuttings followed by softwood cutting when propagated in autumn. On the other hand, it was verified highest root dry weight $(1.7 \mathrm{~g})$ in blackberry herbaceous cuttings when propagated in spring (DIAS et al., 2011).

It is known that tip cuttings present high levels of endogenous auxins which promote rooting process (PAULA et al., 2009; ZUFFELLATORIBAS; RODRIGUES, 2001). In autumn season, air temperature was lower than those in during spring and summer in this work, and also, the relative humidity was high, ranging from 80 and $90 \%$ (Figure 1). These conditions might have promoted better rooting conditions for tip cuttings, avoiding which the occurrence of cutting drought, once the plant tissue of this cutting type is very tender.

For commercial acceptance of a propagation method, blackberry stock plants must produce plant material in large numbers, and the collection and handling of propagation material must be cost effective. A simple, inexpensive method that will generate high numbers of rooted cuttings is preferred (TAKEDA et al., 2011). Thus, from the results enclosed, it is suggested that for optimum use of stock plants at nursery for commercial plants production of blackberry 'Xavante', it is better to use softwood and semihardwood cuttings obtained during summer season. However, in case of no severe winter and availability in stock plants, tips can also be used to produce new nursery plants in greenhouse conditions. It was shown variation regarding the plant multiplication via roots, but the mortality rates was too low when this kind of plant material was used in summer and autumn, resulting in plants of optimum size and adequate number of leaves and roots. Hence the blackberry 'Xavante' can be multiplied using different vegetative parts, such as tip, softwood and semihardwood cutting, and root, but each one has its proper season to promote rooting and plant development. 
TABLE 1 - Conjoint analysis of cutting rooting of different blackberry cuttings types of cv. Xavante under different seasons. Londrina, PR, 2013.

\begin{tabular}{ccccccc}
\hline & & \multicolumn{4}{c}{ Cutting types } & \\
\cline { 3 - 5 } & Seasons & tip & softwood & semihardwood & root & CV (\%) \\
\hline Cutting & Autumn & $88.0 \mathrm{Aa}$ & $72.0 \mathrm{ABa}$ & $46.0 \mathrm{Bb}$ & $74.0 \mathrm{ABab}$ & \\
rooting & Spring & $48.0 \mathrm{Bb}$ & $64.0 \mathrm{ABa}$ & $88.0 \mathrm{Aa}$ & $90.0 \mathrm{Aa}$ & 25.21 \\
$(\%)$ & Summer & $32.0 \mathrm{Cb}$ & $76.0 \mathrm{ABa}$ & $94.0 \mathrm{Aa}$ & $62.0 \mathrm{Bb}$ & \\
\hline
\end{tabular}

Means followed by equal letters in the lines (uppercase) and in column (lower case) do not differ by Tukey's test $(P<0.05)$.

TABLE 2 - Conjoint analysis of cutting survival of different blackberry cuttings types of cv. Xavante under different seasons. Londrina, PR, 2013.

\begin{tabular}{ccccccc}
\hline & & \multicolumn{4}{c}{ Cutting types } & \\
\cline { 3 - 5 } & Seasons & tip & softwood & semihardwood & root & CV (\%) \\
\hline Cutting & Autumn & $88.0 \mathrm{Aa}$ & $80.0 \mathrm{Aa}$ & $86.0 \mathrm{Aa}$ & $98.0 \mathrm{Aa}$ & \\
survival & Spring & $54.0 \mathrm{Bb}$ & $76.0 \mathrm{ABa}$ & $94.0 \mathrm{Aa}$ & $96.0 \mathrm{Aa}$ & 16.81 \\
$(\%)$ & Summer & $40.0 \mathrm{Cb}$ & $80.0 \mathrm{ABa}$ & $96.0 \mathrm{Aa}$ & $68.0 \mathrm{Bb}$ & \\
\hline
\end{tabular}

Means followed by equal letters in the lines (uppercase) and in column (lower case) do not differ by Tukey’s test $(P<0.05)$

TABLE 3 - Conjoint analysis of number of roots per cutting of different blackberry cuttings types of cv. Xavante under different seasons. Londrina, PR, 2013.

\begin{tabular}{ccccccc}
\hline & & \multicolumn{4}{c}{ Cutting types } & \\
\cline { 3 - 6 } & Seasons & tip & softwood & semihardwood & root & CV (\%) \\
\hline Number of & Autumn & $14.6 \mathrm{Aa}$ & $8.2 \mathrm{Ba}$ & $7.6 \mathrm{Ba}$ & $5.1 \mathrm{Ba}$ & \\
roots per & Spring & $5.6 \mathrm{Ab}$ & $7.5 \mathrm{Aa}$ & $9.4 \mathrm{Aa}$ & $8.2 \mathrm{Aa}$ & 32.27 \\
cutting & Summer & $6.4 \mathrm{Ab}$ & $9.2 \mathrm{Aa}$ & $8.4 \mathrm{Aa}$ & $5.7 \mathrm{Aa}$ & \\
\hline
\end{tabular}

Means followed by equal letters in the lines (uppercase) and in column (lower case) do not differ by Tukey's test $(P<0.05)$.

TABLE 4- Conjoint analysis of root length of major roots per cutting of different blackberry cuttings types of cv. Xavante under different seasons. Londrina, PR, 2013.

\begin{tabular}{|c|c|c|c|c|c|c|}
\hline & \multicolumn{5}{|c|}{ Cutting types } & \multirow[b]{2}{*}{$\mathrm{CV}(\%)$} \\
\hline & Seasons & tip & softwood & semihardwood & root & \\
\hline \multirow{3}{*}{$\begin{array}{l}\text { Root } \\
\text { length } \\
(\mathrm{cm})\end{array}$} & Autumn & $20.3 \mathrm{Ab}$ & $16.5 \mathrm{Ab}$ & $11.5 \mathrm{Ab}$ & $16.7 \mathrm{Ab}$ & \\
\hline & Spring & $17.8 \mathrm{Ab}$ & $20.9 \mathrm{Ab}$ & $21.3 \mathrm{Aa}$ & 23.1 Aab & 23.72 \\
\hline & Summer & $36.3 \mathrm{Aa}$ & $33.5 \mathrm{Aa}$ & $29.9 \mathrm{Aa}$ & $29.6 \mathrm{Aa}$ & \\
\hline
\end{tabular}

Means followed by equal letters in the lines (uppercase) and in column (lower case) do not differ by Tukey's test $(P<0.05)$.

TABLE 5 - Conjoint analysis of dry weight of roots per cutting of different blackberry cuttings types of cv. Xavante under different seasons. Londrina, PR, 2013.

\begin{tabular}{ccccccc}
\hline & & \multicolumn{3}{c}{ Cutting types } & \\
\cline { 3 - 6 } & Seasons & tip & softwood & semihardwood & root & CV (\%) \\
\hline \multirow{2}{*}{$\begin{array}{c}\text { Dry weight of } \\
\text { roots per cutting }\end{array}$} & Autumn & $1.40 \mathrm{Aa}$ & $1.28 \mathrm{Aa}$ & $0.14 \mathrm{Bb}$ & $0.32 \mathrm{Ba}$ & \\
$(\mathrm{g})$ & Spring & $0.09 \mathrm{Ab}$ & $0.09 \mathrm{Ac}$ & $0.13 \mathrm{Ab}$ & $0.20 \mathrm{Aa}$ & 49.50 \\
& Summer & $0.20 \mathrm{Bb}$ & $0.59 \mathrm{Ab}$ & $0.68 \mathrm{Aa}$ & $0.31 \mathrm{ABa}$ & \\
\hline
\end{tabular}

Means followed by equal letters in the lines (uppercase) and in column (lower case) do not differ by Tukey's test $(P<0.05)$. 


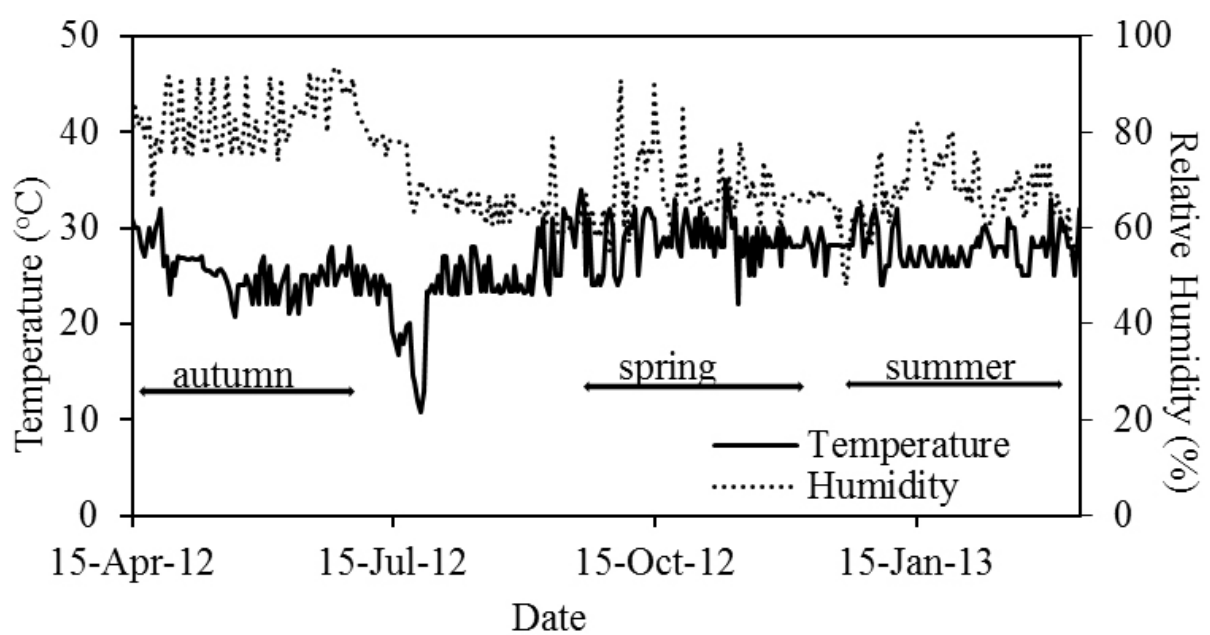

FIGURE 1- Daily mean temperature $\left({ }^{\circ} \mathrm{C}\right)$ and relative humidity $(\%)$ during autumn, spring and summer inside the greenhouse.

\section{CONCLUSION}

Softwood and semihardwood cuttings collected in summer are the best option for blackberry $\mathrm{cv}$. Xavante multiplication for commercial production of nursery plants.

\section{ACKNOWLEDGEMENTS}

The authors thank Brazilian National Council for Scientific and Technological Development (CNPq) and The World Academy of Sciences (TWAS) for financial support.

\section{REFERENCES}

ANDRADE, R.A.; MARTINS, A.B.G.; SILVA, M.T.H.; TUROLLA, I.G. Propagação da amora-preta por estaquia utilizando ácido indolbutírico. Revista Caatinga, Mossoró, v.20, n.2, p.79-83, 2007.

ANTUNES, L.E.C.; RASEIRA, M.C.B. Aspectos técnicos da cultura da amora-preta. Pelotas: Embrapa Clima Temperado, 2004. 54p. (Documentos, 122).

CALDWELL, J.D. Blackberry propagation. HortScience, Alexandria, v.19, n.2, p.13-15, 1984.
CAMPAGNOLO, M.A.; PIO, R. Rooting of stems and root cutting of blackberry cultivars collected in different times, cold storage and treatment with IBA. Ciência Rural, Santa Maria, v.42, p.232-237, 2012.

CLARK, J.R.; FINN, C.E. Blackberry cultivation in the world.Revista Brasilera de Fruticultura, Jaboticabal, v.36, n.1, p.46-57, 2014.

CONTADOR, M.L.; COMAS, L.H.; METCALF, S.G.; STEWART, W.L.; GOMEZ, I.P.; NEGRON, C.; LAMPINEN, B.D.Root growth dynamics linked to above-ground growth in walnut (Juglans regia). Annals of Botany, Oxford, v.116, p.49-60, 2015.

DIAS, J.P.T.; ONO, E.O.; DUARTE FILHO, J.Enraizamento de estacas de brotações oriundas de estacas radiculares de amoreira-preta. Revista Brasileira de Fruticultura, Jaboticabal, v.33, n.1, p.649-653, 2011.

FACHINELLO, J.C.; HOFFMANN, A.; NACHTIGAL, J.C. Propagação de plantas frutíferas. Brasília, DF: Embrapa Informação Tecnológica, 2005. 221p.

HARBORNE, J.B.; WILLIAMS, C.A. Advances in flavonoid research since 1992. Phytochemistry, New York, v.55, p.481-504, 2000. 
HARTMANN, H.T.; KESTER, D.E.; DAVIES JUNIOR, F.T.; GENEVE, R.L. Plant propagation: principles and practices. $7^{\text {th }}$ ed. New Jersey: Prentice Hall, 2002. 880p.

HUSSAIN, I.; KHATTAK, A.M.; AMIN, N.; AMAN, F.; SAJID, M.Response of different pomegranate cuttings types to different environmental conditions. Sarhad journal of Agriculture, Peshawar, v.28, n.1, p.15-18, 2012.

HUSSAIN, I.; ASSIS, A.M.; YAMAMOTO, L.Y.; KOYAMA, R.; ROBERTO, S.R.Indole butyric acid and substrates influence on multiplication of blackberry 'Xavante'.Ciência Rural, Santa Maria, v.44, n.10, 2014.

HUSSAIN, I.; ROBERTO, S.R.; FONSECA, I.C.B.; ASSIS, A.M.; KOYAMA, R.; ANTUNES, L.E.C. Phenology of 'Tupy' and 'Xavante' blackberries grown in a subtropical area. Scientia Horticulturae, Wageningen, v.201, p.78-83, 2016.

HUSSAIN, I.; ROBERTO, S.R.; KOYAMA, R.; ASSIS, A.M.; COLOMBO, R.C.; FONSECA, I.C.B.; ANTUNES, L.E.C. Performance of 'Tupy' and 'Xavante' blackberries under subtropical conditions. Fruits, v.72, n.3, p.166-173, 2017.

KASIM, N.; RAYYA, A.; SHAHEEN, M.; YEHIA, T.; ALI, E.Effect of different collection times and some treatments on rooting and chemical internal constituents of Bitter Almond hardwood cuttings. Research Journal of Agriculture and Biological Sciences, New York, v.5, p.116-122, 2009.

LEITE, J.B.V.; MARTINS, A.B.G.Efeito do ácido indolbutírico e época de coleta no enraizamento de estacas semi-lenhosas do cacaueiro.Revista Brasileira de Fruticultura, Jaboticabal, v.29, n.2, p.204-208, 2007.

MAIA, A.J.; BOTELHO, R.V. Reguladores vegetais no enraizamento de estacas lenhosas da amoreirapreta cv.Xavante. Semina: Ciências Agrárias, Londrina, v.29, n.2, p.323-330, 2008.

MOREIRA, R.A.; RAMOS, J.D.; CRUZ, M.C.M.; VILLAR, L.; HAFLE, O.M. Ácido indolbutírico e polímero hidroabsorvente no enraizamento de estacas de amoreira-preta. Scientia Agraria Paranaenis, Marechal Cândido Rondon, v.11, n.1, p.74-81, 2012.
OHLAND, T.; PIO, R.; CHAGAS, E.A.; BARBOSA, W.; KOTZ, T.E.; DANELUZ, S. Enraizamento de estacas apicais de figueira 'Roxo de Valinhos' em função de época de coleta e AIB. Ciência e Agrotecnologia, Lavras, v.33, n.1, p.74-78, 2009.

PAULA, L.A.; CORRÊA, L.S.; BOLIANI, A.C.; SANTOS, P.C. Efeito do ácido indolbutírico e épocas de estaqueamento sobre o enraizamento de estacas herbáceas de figueira (Ficus carica L.). Acta Scientiarum Agronomy, Maringá, v.31, n.1, p.87-92, 2009.

PICOLOTTO, L.; VIGNOLO, G.K.; PEREIRA, I.S.; GONÇALVES, M.A.; ANTUNES, L.E.C. Enraizamento de estacas de amoreira-preta em função da adubação nitrogenada na planta matriz. Revista Ceres, Viçosa, MG, v.62, n.3, p.294-300, 2015.

RAHMAN, H.M.A.; KHOKAR, K.; LAGHARI, M.H. Effect of season of rooting on the ability of cuttings of Guava (Psidium guajava). Indian Journal of Agricultural Sciences, New Delhi, v.16, p.404-406, 1991.

RAPAKA, V.K.; BESSLER, B.; SCHREINER, M.; DRUEGE, U. Interplay between initial carbohydrate availability, current photosynthesis, and adventitious root formation in Pelargonium cuttings. Plant Science, Ireland, v.168, p.1547-1560, 2005.

SALMI, M.S.; HESAMI, M. Time of collection, cutting ages, auxin types and concentrations influence rooting Ficus religiosa L.stem cuttings. Journal of Applied Environmental and Biological Sciences, Egypt, v.6, p.124-132, 2016.

SILVA, K.N.; PIO, R.; TADEU, M.H.; ASSIS, C.; NCURI, P.N.; MOURA, P.H.A.; PATTO, L.S. Seedling production of black raspberry by different methods of vegetative propagation. Ciência Rural, Santa Maria, v.42, n.3, p.418-422, 2012.

SOUNDY, P.; MPATI, K.W.; DU TOIT, E.S.; MUDAU, F.N.;ARAYA, H.T. Influence of cutting position, medium, hormone and season on rooting of fever tea (Lippia javanica L.) stem cuttings. Medicinal and Aromatic Plant Science and Biotechnology, Isleworth, v.2, n.2, p.114-116, 2008. 
SWAMY, S.; PURI, S.; SINGH, A. Effect of auxins (IBA and NAA) and season on rooting of juvenile and mature hardwood cuttings of Robinia pseudoacacia and Grewia optiva. New Forests, Oklahoma, v.23, p.143-157, 2002.

TAKEDA, F.; TWORKOSKI, T.; FINN, C.; BOYD, C. Blackberry propagation by non-leafy floricane cuttings. HortTechnology, Alexandria, v.21, n.2, p.236-239, 2011.

VILLA, F.; PIO, R.; CHALFUN, N.N.J.; GONTIJO, T.C.A.; DUTRA, L.F. Propagation of blackberry using of woody cutting.Ciência e Agrotecnologia, Lavras, v.27, p.829-834, 2003.
YAMAMOTO, L.Y.; KOYAMA, R.; BORGES, W.F.S.; ANTUNES, L.E.C.; ASSIS, A.M.; ROBERTO, S.R. Substrates on rooting of blackberry Xavante herbaceous cuttings. Ciência Rural, Santa Maria, v.43, n.1, p.15-20, 2013.

YOO, Y.K.; KIM, K.S. Seasonal variation in rooting ability, plant hormones, carbohydrate, nitrogen, starch, and soluble sugar contents in cuttings of white forsythia (Abeliophyllum distichum Nakai). Journal of the Korean Society for Horticultural Science, Seoul, v.37, p.554-560, 1996.

ZUFFELLATO-RIBAS; C.K.; RODRIGUES, D.J. Estaquia: uma abordagem dos principais aspectos fisiológicos. Curitiba: EUFPR, 2001.39p. 